\title{
TEACHERS' TECHNIQUES IN TEACHING ENGLISH VOCABULARY TO YOUNG LEARNERS
}

\author{
Maulani Agustin \\ STKIP Pasundan, Indonesia \\ Email: laniagustin9@gmail.com \\ First Received: February 2019 \\ Final Proof Received: March 2019
}

\begin{abstract}
This research aimed at investigating the techniques used by teacher in teaching English vocabulary of young learners as well as the reasons employing the techniques. Observations and interview were carried out to collect the data. The respondent of this research was the English teacher and the object is the process of technique in teaching English vocabulary. Based on the data collection, the researcher concluded that the techniques used by the English teacher were Spelling Rules and Keeping Record. The media used by the teacher was song. The reason why the teacher used those techniques were: (1) Help the students remember their vocabulary, (2) Attract the students' attention to the lesson, (3) The techniques can be used in any situation.
\end{abstract}

Keywords: Teaching techniques, vocabulary, young learners

\section{INTRODUCTION}

English vocabulary has a vital part in learning English. Thornburry (2002) states that, "without grammar everything can be conveyed, without vocabulary nothing can be conveyed" (p. 13). In addition, Caroline (2005) states that vocabulary is a meaning and uses words in appropriate structure. Without vocabulary people cannot understand the meaning of the language. The role of words is important to know how the language is used, practiced, and communicated (p. 121).

Young learners have a short attention to the lesson. Krashen (as cited in Gursoy, 1973) states that, "lateralization of the brain is complete before puberty, and it is not a barrier to accent-free second language learning by adults" (p. 63). In addition, Halliwell (1992) states that young learners have a very good interpreting meaning without understanding the individual word, they have a great skill in using limited language creatively. Because, young learners take a great delight in talking. They frequently learn indirectly rather than directly and young learners have a great pleasure in creating fun whatever they do with their own imagination" (p. 335).

\section{Kinds of Vocabulary}

Some experts divided vocabulary into two kinds. According to Gairn and Redman (as cited in Lestari, p. 11), they put their opinion about kinds of vocabulary:

\section{Receptive vocabulary}

Receptive vocabulary is words items which can only be recognized and comprehended in the context of reading and listening material but do not use it in speaking and writing.

\section{Productive vocabulary}

Productive vocabulary is the words that the learners understand and can pronounce correctly and use constructively in speaking and writing. Productive vocabulary can be addressed as an active process. 


\section{Teacher Techniques in Teaching Vocabulary}

The researcher uses Thornburry's research (2002) about teacher techniques in teaching vocabulary. There are eight techniques in teaching vocabulary according to Thornburry (2002, p. 144), there are:

a. Learner Training

The teacher plays as a major role in motivating learners to take vocabulary and giving the student ideas on how to learn vocabulary.

b. Using Mnemonics

Mnemonics should have two important elements, visual elements and selfgenerated. This technique involves devising an image that typically connects the pronunciation of the second language word with the meaning of a first language word.

c. Word Cards

Learners write down a word on the one side of small card with mother tongue vocabulary, and then the learners translate it into English on the other side.

d. Guessing from Context

Guessing from the contest is probably one of the most useful skills learners can acquire and apply both inside and outside the classroom. The problem for the most learners when guessing the meaning of words in a second language is that they are less confident about their understanding of the context than they would be in their mother tongue.

e. Coping Strategies for Production

Coping strategies for production is a strategy that help learners cope when speaking or writing. The learners use vague language to get around the problem of not knowing a word.

f. Using Dictionaries

Using dictionaries usefulness depends on learners being able to access the information they contain both speedily and accurately. Training learners in effective dictionary use in particularly important since many learners may not be familiar with dictionary conventions, even in their own language.

g. Spelling Rules

Dictionaries are often used to check spelling, and spelling in English is somewhat problematic.

h. Keeping Records

Keeping records have a point to help the student to records their English vocabulary.

Mostly, students will forget about the vocabulary that they have learned in class.

\section{Media in Teaching English Vocabulary to Young Learners}

There are some tips of media that used in teaching English vocabulary by Slattery and Willis (2001) (1) make class displays of pictures and other memory aids to support new vocabulary, (2) prepare to teach new words and phrases in a meaningful way by linking with the topic that the students are familiar with, (3) show the students how to play 
vocabulary games and give instruction in English while doing games, and (4) use lots of different games but use the same vocabulary to help the students become familiar with it.

New words and phrases need to be used a lot after introducing them so that the students learn to use them actively.

\section{Characteristics of Young Learners}

Cameron (2001, p. 2) mention that young learners learn differently from adolescence and adults in the following ways:

a. The Child as an Active Learner

Piaget's theory concerned to how young learners' function in the world surrounds them, and how this influences their mental development. From Piagetian viewpoint, children thinking develop gradual growth of knowledge and intellectual skill towards a final stage of formal, logical thinking.

b. The Child as sense-maker

Young learners as an active learner and thinker construct their own knowledge from working with object or ideas. They seek out intentions and purposes in what they see other people doing, bringing their knowledge and experience to their attempts to make sense of other people's action and language.

c. The Child as Social Being

Vygotsky's view of children is an active learner in a world full of objects. Those people play important roles in helping children to learn, bringing objects and ideas to their attention.

\section{METHOD}

This research is only limited to describe what kind of techniques in teaching vocabulary, and apply the most appropriate technique according to condition of the student at the fifth grade of one of elementary school at Ngamprah.Creswell (2009) states that qualitative research tends to collect data in the field at the site where participants experience the issue under research. Gathering information by talking directly to people and seeing them behave and act within their context is a major characteristic of qualitative research (p. 175).

In this research, the researcher used descriptive qualitative method to find out what type of techniques that the teacher uses in teaching English vocabulary. Subject of this research is the teacher of fifth grade students in one of elementary school in Ngamprah.

The observation used two instruments, there are field note and recorder/camera digital. In addition, the documentation was done through recording and taking pictures to get more information related to the research problems. Besides that, the researcher used interview to strengthen the data from observation and documentation. For the interview, there two instruments that used by the researcher: an interview guide and a recorder.

\section{FINDINGS AND DISCUSSION}

The findings were gained by using classroom observation and teacher interview. Based on the observation which was conducted three times, the researcher acquired the techniques that the teacher used in teaching English vocabulary and the reason why the teacher used those techniques. 
Table 1. Observation

\begin{tabular}{lccc}
\hline \multirow{1}{*}{ Technique } & Observation 1 & Observation 2 & \multirow{2}{*}{ Media } \\
\cline { 2 - 3 } & March 5, 2019 & March 6, 2019 & \\
\hline Spelling rules & The first step & The second step & Song \\
\hline Keeping Record & The second step & The first step & Song \\
\hline
\end{tabular}

Table 2. Observation details

\begin{tabular}{|c|c|c|}
\hline Observation & Technique & Details \\
\hline \multirow[t]{3}{*}{ Observation I } & Spelling Rules & $\begin{array}{l}\text { "T: So I will check you pronunciation. } \\
\text { I will check your alphabet. } \\
\text { (the teacher wrote on the board) } \\
\text { Spell it } \\
\text { S: K E Y" }\end{array}$ \\
\hline & Keeping Record & "Write down on your notebook" \\
\hline & Song & $\begin{array}{l}\text { "A B C D E F G H I J K L M N O P Q R S T U V W } \\
\text { X Y and Z. Now I know my A B C" }\end{array}$ \\
\hline \multirow[t]{3}{*}{ Observation II } & Spelling Rules & $\begin{array}{l}\text { "T: Listen to this. } \\
\text { S: Spon } \\
\text { T: S P double O N. Spoon } \\
\text { S: Spoon" }\end{array}$ \\
\hline & Keeping Record & $\begin{array}{l}\text { "T: I want to check you book first. } \\
\text { Open your book and collect that to my table. Who } \\
\text { write many vocabularies?" }\end{array}$ \\
\hline & Song & $\begin{array}{l}\text { "A B C D E F G H I J K L M N O P Q R S T U V W } \\
\text { X Y and Z. Now I know my A B C. Let's sing it with } \\
\text { me" } \\
\text { "Good bye mama. Good bye papa. We will meet } \\
\text { again. Good bye mama. Good bye papa. I miss you" }\end{array}$ \\
\hline
\end{tabular}

From the data above, the teacher used spelling rules and keeping records to introduce the new material to the students. Alderman \& Green (2011) state that "learning vocabulary through spelling can increase motivation of the student to learn" (p. 604). There are some rules in using Spelling Rules in teaching vocabulary, and the teacher used the rules while using Spelling Rules technique in teaching English vocabulary to young learners.

\section{Dictate}

The teacher dictated the number of words first, in addition the teacher include only word that the student familiar with it.

\section{Write}

The teacher asked learners to write what words that the student have learned, and then make a sentence with that word.

In keeping records, the teacher used some steps. The first is, the teacher advised students to have a special notebook for vocabulary. The second, the teacher asked learners regularly to compare and comment on their vocabulary notebooks. Third, the teacher asked the students to make a short sentence using that vocabulary. The last, the teacher should have to check students' vocabulary notebook time to time.

The teacher used song as a media to help the students learned how to spell a good alphabet. Murphy (1992) states that, the use of music and songs can stimulate the students very positively in association with the study of a language (p. 17). There are some reasons that the teacher used song in teaching English, there are. 
Song is memorable; the students will remember the difficult word by singing a song. Griffe (1992) states that, "songs can be used for pattern practice and memory relation" (p. 6). Students have a great motivation in learning vocabulary through song. Kusnierek (2016) states that, "songs touch the lives of students, they are connected with students' various interest and everyday experiences" (p. 24).

Song allowed for lots of repetition of the language without the students getting bored. Martin (2000) states that, "Song can represent powerful features of primary language programs. Using song can make the students happy and satisfied to the class" (p. 69).

The teacher combined two different techniques in teaching English vocabulary. The teacher used Keeping Records to keep the students remember their material that they have learned before. When the teacher used Spelling Rules to help the students knew and spell a word, Keeping Record help the students to remember the words that they have learned.

The teacher believes that every single student is different, there are talkative students and quiet students. In order to make sure that the lesson is accepted by the whole students, the teacher gives motivation to the students who shy to express their thought.

Table 3. Interview

\begin{tabular}{|c|c|c|}
\hline Code & Description & Excerpt \\
\hline \multirow[t]{2}{*}{ Techniques } & Spelling Rules & $\begin{array}{l}\text { Spelling Rules can make the atmosphere of } \\
\text { the class more enjoyable. }\end{array}$ \\
\hline & Keeping Record & $\begin{array}{l}\text { The students can remember the word that } \\
\text { they have learned before. }\end{array}$ \\
\hline \multirow[t]{2}{*}{ Reason } & Criteria & $\begin{array}{l}\text { The students will be ready for the lesson, } \\
\text { because the teacher will check their } \\
\text { notebook before learning process and test } \\
\text { the students }{ }^{\text {ee }} \text { vocabulary. }\end{array}$ \\
\hline & Improving the techniques & $\begin{array}{l}\text { Giving extra assignment for them } \\
\text { (homework). } \\
\text { Using realia outside the classroom. } \\
\text { Take the example that familiar to the } \\
\text { students. }\end{array}$ \\
\hline Media & Song is the best media to get $\mathrm{s}$ & tention in learning English vocabulary. \\
\hline $\begin{array}{l}\text { Classroom } \\
\text { management }\end{array}$ & \multicolumn{2}{|c|}{ Giving motivation to the students by asking the students to write on the white board. } \\
\hline
\end{tabular}

Referring to the data analyzing above, the teacher used Keeping record and Spelling Rules in teaching 5 grade students as a suitable technique for them. The teacher has considered the situation of the school, the class, and the students itself before choosing what kind of technique that the teacher will use before entering the class.

\section{CONCLUSION}

The result of the research revealed that in teaching learning process in teaching English vocabulary, the teacher applied different techniques with different reasons. The teacher used Spelling Rules in teaching vocabulary. One of the reasons is because Keeping records can make the atmosphere of the class funnier. Other techniques, keeping records were employed to help the students remember the vocabulary that they have learned before.

Before presenting meaning or form of vocabulary items, teachers need to notice some considerations such as the type of the vocabulary, the students se level, and characteristics, as well as the value of the techniques for the leaners. Teachers are 
suggested to use interactive media in teaching English vocabulary for example using song as a media in learning process. It will help the students remember word better.

\section{REFERENCES}

Alderman, G. L. \& Green, S. K. (2011). The reading Teacher, Fostering Lifelong Spellers Through Meaningful Experiences, 64(8), 599-605.

Cameron, L. (2001).Teaching Languages to Young Learners. Cambridge, England: Cambridge University Press.

Caroline, L. T. (2006). Teaching Vocabulary to Young Learners, New York: McGraw Hill.

Creswell, J.W. (2009). Research Design: Quanlitative, quantitative, and Mixed Method Approaches, Third Edition. United States of America: SAGE Publicantions, Inc.

Graints, R \& Redman, S. (1986). Working with Words a Guide to Teaching and Learning, New York: Cambridge University Press.

Griffe, D. T. (1992), Songs in action. Hertfordshire, England: Prentice Hall.

Halliwell, S. L. (1992). English Language Teaching. Teaching English in the Primary Classroom. 49 (4). 355 - 357.

Krashen, S. D. (1973). Lateralization, Language Learning, and Critical Period: Some New Evidence. Language Learning. Los Angles, California: ISI

Kusnierek, A. (2016). World Scientific News, The Role of Music and Songs in Teaching English Vocabulary to Students, 43(1), 1-55.

Martin, C. (2000). An Analysis of National and International Research on the Provision of Modern Foreign Languages in Primary Schools. London: Qualifications and Curriculum Autorithy.

Murphey, T. (1992). Music and Song. Oxford: Oxford University Press.

Slattery, M. \& Willis, J. (2011). English for Primary Teachers. England: Oxford University Press.

Thornburry, S. (2002). How to Teach Vocabulary. Edinburg Gate, England: Pearson. 